\section{Our hands at work: Indigenous food sovereignty in Western Canada}

\author{
Tabitha Robin * \\ University of Manitoba
}

\author{
Special JAFSCD Issue \\ Indigenous Food Sovereignty in North America \\ sponsored by
}

\section{Swette Center for Sustainable Food Systems} Arizona State University

Submitted February 13, 2019 / Revised March 11 and March 14, 2019 / Accepted March 14, 2019 /

Published online October 15, 2019

Citation: Robin, T. (2019). Our hands at work: Indigenous food sovereignty in Western Canada.

Journal of Agriculture, Food Systems, and Community Development, 9(Suppl. 2), 85-99.

https://doi.org/10.5304/jafscd.2019.09B.007

Copyright (C) 2019 by the Authors. Published by the Lyson Center for Civic Agriculture and Food Systems. Open access under CC-BY license.

\begin{abstract}
Food sovereignty has recently emerged as a means of addressing pervasive food-related problems in many Indigenous communities in Canada as well as around the world. This is particularly important for Indigenous people who still face threats to their food systems directly stemming from colonialism. Stories of community-based Indigenous food sovereignty are presented in this paper. Outcomes are summarized using a circle metaphor that describes four key elements of Indigenous food sovereignty that emerged from this research: history, connection to the land, relationships, and identity. Indige-
\end{abstract}

* Tabitha Robin, Ph.D. candidate, Faculty of Social Work, University of Manitoba; 521 Tier Building; Winnipeg, MB R3T 2N2 Canada; tabitha.martens@umanitoba.ca

\section{Author Note}

This research is based on my master's research at the University of Manitoba. Funding for my Master's was received through the Manitoba NEAHR Program (Network Environment for Aboriginal Health Research), part of the Canada Institute for Health Research (CIHR). nous food sovereignty requires that we move beyond access to food, and critically interrogate Indigenous relationships to food. This is founded upon the notion that people should be able to be self-determinant in their own food and cultural traditions. Progress requires a shift in how Indigenous food relationships are understood and incorporating Indigenous worldviews and perspectives as part of a larger resurgence movement.

\section{Keywords}

Indigenous Food Sovereignty, Traditional Food, Indigenous Research Methodologies, Resurgence, Self-Determination

\section{Introduction}

Many Indigenous peoples in Canada experience challenges in accessing fresh, affordable, and appropriate foods that are the mainstays of Indigenous diet and cultures. Remote, isolated communities face particular obstacles in the realm of food security. On average, the rate of food insecurity among Indigenous peoples in Canada higher than 
among their non-Indigenous counterparts (Health Canada, 2007). A long history of colonization, including the destruction of animals, land, waterways, and connections to Indigenous ways of life, has deeply impacted Indigenous peoples' wellbeing, self-determination, and food security (Kelm, 1999; Lux, 2001; McCallum, 2017; McLachlan, 2014; Shewell, 2004; Truth and Reconciliation Commission, 2015).

However, Indigenous communities are responding to these challenges through a resurgence of traditional relationships between peoples, land, food, education, and ceremony. Indeed, these elements are part of an interconnected whole. Food sovereignty, while a "living reality" for Indigenous peoples in Canada, has recently emerged in the literature as a means to understand and document the connections between Indigenous peoples and their food systems (Morrison, 2011). Expressions of food sovereignty vary from place to place and nation to nation. In Canada, much of what has been documented involves gardens and greenhouses (First Nations Health Council, 2009; Mundel \& Chapman, 2010; Skinner, Hanning, \& Metatawabin, 2014; Stroink \& Nelson, 2009). Yet Indigenous food sovereignty takes many forms and engages in spaces beyond gardens and waters and land. Many of these initiatives are embedded in community, and there has been little opportunity for communities to share and learn from one another. The food issues facing Indigenous communities continue to be presented in negative ways, and good news stories and Indigenous voices are often missing from media accounts (Follett, 2010; Sloan-Morgan \& Castleden, 2014). Tuck (2009) has described the harm of "damage centered" research that continues to perpetuate notions that Indigenous peoples and their communities are damaged and exist in a state of defeat. Further challenges include the presence of racism in media accounts (Anderson \& Robertson, 2011; Harding, 2006) and the misrepresentation of Indigenous voices and positions (Follett, 2010). However, good news stories can "facilitate, through the narrative tradition, the successful exchange of information" (Vazquez, 2011, p. 2) within and among Indigenous communities. Sharing good news stories in a broader context would provide an opportunity for the public to learn how to ensure the health and safety of the land for future generations (Cajete, 1999).

This contribution creates a new discourse around good food stories in Indigenous communities based on a series of interviews with knowledge holders, Elders, harvesters, activists, and landbased peoples in an attempt to understand what Indigenous food sovereignty looks like in western Canada. These stories offer an alternative approach: one in which Indigenous peoples are represented, can speak to the damages of colonialism, and have opportunities to direct their food and land-based projects in a way that promotes and protects food, culture, and land.

\section{Food Sovereignty}

To articulate the struggles of the political and economic systems characterizing food production, the term "food sovereignty" was proposed by La Vía Campesina in 1996. As Wittman, Desmarais, and Wiebe (2010) share, Indigenous communities were no longer guaranteed local access to culturally appropriate and nutritious food. Food sovereignty has been described as:

... the right of peoples to decide and produce their own food. It is a political right to organize ourselves, to decide what to plant, to have control of seeds. Food sovereignty is a very broad concept that includes the right of access to seeds, the right to produce, to trade, to consume one's own foods. . . . [] t is a concept that is linked to the autonomy and sovereignty of peoples. (Masioli \& Nicholson, 2010, p. 34)

While La Vía Campesina's view of food sovereignty works toward developing community independence, it is important to note that it does not necessitate the sole independence of community food production (Patel, 2012). There is room for communities to create their own visions of food sovereignty and define their own food systems. Food sovereignty also advocates for strengthening relationships to food, to the land, and to food providers-who, in many instances, are women. One of the strengths of food sovereignty is its campaign to end violence against women (Patel, 2012; 
Wittman et al., 2010).

The food sovereignty movement in Canada has been visible largely through the National Farmer's Union and the Union Paysanne, nonprofit organizations working in the international agriculture arena such as the Unitarian Service Committee of Canada, Indigenous movements such as the Working Group on Indigenous Food Sovereignty, and urban food security networks such as Food Secure Canada, although less information has been shared explicitly about the work of Indigenous food sovereignty efforts (Andrée, Cobb, Moussa, \& Norgang, 2011; Desmarais \& Wittman, 2014). Despite the promise of these endeavors, food sovereignty in Canada is not without its challenges. The displacement of family farms, the relatively short history of agriculture in Canada, and the fragmentation of human and land relationships resulting from urbanization are all issues that need to be addressed (Desmarais \& Wittman, 2014).

The complexity and diversity of Indigenous food systems are a further challenge to food sovereignty in Canada. Indigenous food systems fall into the realm of cultural and political resurgence and include "a sovereignty of having the right to produce culture" (Masioli \& Nicholson, 2010, p. 34).

\section{Indigenous Sovereignty}

This discussion focuses on the intersections between Indigenous sovereignty and Indigenous food sovereignty (IFS). For example, it is nearly impossible for peoples of the land to obtain food from the land if that land is not protected (Morrison, 2011). ${ }^{1}$ With myriad definitions and understandings of sovereignty for Indigenous peoples (see, for example, Grey \& Patel, 2015; Porter, 2005; Varese, 2010), the evolution and applicability of the term are problematic. Current constructs of Indigenous sovereignty have been criticized as incompatible with traditional Indigenous notions of power and control (Alfred, 2009). Alfred has argued that the contemporary sovereignty discourse remains grounded in Western goals of sovereignty and colonialism. Daigle (2017, p. 4) shares how "Eurocentric notions of sovereignty that are based on Lockean concepts of land as property" are a stark contrast to Indigenous epistemologies in which land is seen as an inherent responsibility that Indigenous people have with creation (Morrison, 2011). Sovereignty discourses must respect values, languages, and identity as part of Indigenous epistemologies that ultimately arise from the land. According to Simpson (2008), land is key:

In the times prior to colonization, Indigenous peoples lived in independent, sovereign nations governed by complex political and social systems. Rooted in the land, with a strong spiritual and religious foundation, these systems ensured our citizens were taken care of and that contentious issues were resolved in a peaceful and just manner. (p. 13)

Western notions of Indigenous sovereignty are at odds with Indigenous food sovereignty specifically. In the context of food sovereignty, Desmarais and Wittman (2014) have argued for stepping back from the historical and legal meanings of sovereignty to focus on supporting relationships, connections, and interdependency between communities. From a conversation with Ray Halbritter, an Oneida lawyer, Alfred (2009) shares Ray's views on sovereignty as "self-sufficiency" (p. 220). Perhaps this is the lens from which we can move the discourse around Indigenous food sovereignty forward. The ability to self-determine both food and political systems works toward achieving harmony and balance in community and ultimately supports well-being. Self-determination must exist within and beyond food to include the ability of Indigenous peoples to self-determine their own futures.

\section{Indigenous Food Sovereignty}

In practice, Indigenous food sovereignty has been visible in communities around the world for thousands of years. Though described as a living reality that sustained Indigenous peoples for millennia,

\footnotetext{
1 While Indigenous cultures in North America and around the world contain a multitude of cultural expressions, some foundational concepts are similar. Importantly, the presence of land as part of identity, history, and spirituality is used here to describe Indigenous peoples as people of the land (Dumont, 2014; Morrison, 2011).
} 
Indigenous food sovereignty has more recently gained renewed strength as a movement and a way of life to address the broken connections between people, land, water, food, and culture. In the context of colonial histories, Indigenous food sovereignty begins to diverge from food sovereignty to focus on such issues as treaties, government policy, and land reform, all issues that prevent people from practicing their culture (People's Food Policy Project [PFPP], 2011).

The study of Indigenous food sovereignty in Canada first arose due to grassroots movements such as British Columbia's Working Group on Indigenous Food Sovereignty (WGIFS), and then later through the work of Food Secure Canada's Indigenous Circle of advisors (PFPP, 2011; WGIFS, 2011). These groups fought for the redistribution of land and for land reform legislation to ensure that people living in traditional territories had access to food from their land (PFPP, 2011; WGIFS, 2011). As Morrison (2011) affirms, "Indigenous food sovereignty is ultimately achieved by upholding our long-standing sacred responsibilities to nurture healthy, interdependent relationships with the land, plants, and animals that provide us with our food" (p. 100).

The importance of self-determination as part of Indigenous ways of life, including Indigenous food systems, has been stated by numerous authors (Bell-Sheeter, 2004; Cidro \& Martens, 2014; First Nations Health Council, 2009; Morrison, 2011). The sacredness of food has also been articulated as a critical element of Indigenous food sovereignty (LaDuke, 2005; Morrison, 2011; PFPP, 2011). Indigenous food sovereignty initiatives have been documented by researchers across Canada and the United States. For example, the White Earth Land Recovery Project in Minnesota and the fight to protect their wild rice from genetically modified seeds have been shared (LaDuke, 2005). In Manitoba, Rudolph and McLachlan (2013) discuss the need for politicized action to support IFS. Rudolph (2012) has also shared her master's research around land-based skill development. IFS has also been examined through a country foods program in O-Pipon-Na-Piwin Cree Nation, Manitoba (Kamal \& Thompson, 2013). Cidro and Martens (2014) found that despite experiences of food insecurity, participation by urban Indigenous peoples in traditional and land-based food activities contributed to feelings of working towards Indigenous food sovereignty. At the Urban Aboriginal Garden Project in British Columbia, Mundel and Chapman (2010) discovered that participants viewed gaining more food skills to be empowering and decolonizing. In her work with Anishinaabe communities, Daigle (2017) found that "the role of food harvesting and sharing practices has been central to this larger process of decolonization and self-determination" (p. 13). Clearly, understandings of Indigenous food sovereignty are expanding into new realms and territories as part of a larger resurgence.

\section{Research Design}

Although the design for this research evolved over time, an Indigenous research framework was used to help guide the process and position Indigenous knowledge at the forefront (Kovach, 2009). As Battiste and colleagues note (2002), this is particularly important for decolonizing research. Elements of the framework included an epistemology based upon the value of experiential and lived knowledge, along with guiding methodological values of respect, relationships, and reciprocity (Hart, 2010; Kovach, 2009; Wilson, 2008).

It is here that I situate myself in my research and writing. As part of my culture, I understand that I am accountable to my research participants, but also to the land, water, sky, and beyond. The relationships formed through this research supported my own cultural identity and helped me understand the ways that identity and selfdetermination intersect.

Using existing contacts and Internet searches, along with a snowball approach, 24 Indigenous food initiatives were identified in western Canada (Table 1), and 32 individuals were interviewed regarding these projects. These initiatives are located on reserve, in Metis territories, and in some cases, a combination of urban and reserve lands. Approval from the University of Manitoba Fort Garry Campus Research Ethics Board was obtained prior to conducting interviews. All but one participant declined anonymity on their consent forms, and thus their names are associated 
with their words. Interviews were audio-recorded with the permission of the participants and transcribed by a research assistant, except in cases where participants asked that I transcribe their interview. Most of these interviews took place over the phone, although I made every effort to meet in person when requested. Participants were asked to describe their food initiatives and to share any promising practices and any challenges they experienced.

\section{Table 1. Summary of the Projects Involved in this Research}

\begin{tabular}{|c|c|c|}
\hline Project Name & Location & Project Focus \\
\hline Ahms Tah Ow School Garden & Sliammon First Nation, BC & school garden \\
\hline Alexis First Nation Greenhouse & Alexis Nakota Sioux First Nation, AB & greenhouse \\
\hline Back to the Land Camp & Peguis First Nation, MB & traditional foods education \\
\hline $\begin{array}{l}\text { BC Food Systems Network Working Group } \\
\text { on Indigenous Food Sovereignty }\end{array}$ & $\mathrm{BC}$ & $\begin{array}{l}\text { research, action, and } \\
\text { policy/advocacy }\end{array}$ \\
\hline BEADS Program & Canim Lake Band, Shuswap Nation, BC & market garden cooperative \\
\hline Cha Me Ta Ha-uuk Hesquiaht Project & Hesquiaht First Nation, BC & community garden \\
\hline Coastal Stewardship Network & $\begin{array}{l}\text { Gitga'at, Haida, Haisla, Heiltsuk, } \\
\text { Kitasoo/Xai'Xais, Metlakatla, Nuxalk \& } \\
\text { Wuikinuxv First Nations, BC }\end{array}$ & $\begin{array}{l}\text { biomonitoring and ocean } \\
\text { stewardship }\end{array}$ \\
\hline Community Based Monitoring & $\begin{array}{l}\text { Athabasca Chipewyan First Nation \& } \\
\text { Mikisew Cree First Nation, AB }\end{array}$ & biomonitoring program \\
\hline $\begin{array}{l}\text { Dog Creek \& Canoe Creek Community } \\
\text { Garden }\end{array}$ & $\begin{array}{l}\text { Dog Creek \& Canoe Creek Communities, } \\
\text { Canoe Creek Band, Secwepemc First } \\
\text { Nation, BC }\end{array}$ & market garden \\
\hline Cree8 Co-op & Flying Dust First Nation, SK & market garden cooperative \\
\hline Earth Boxes & Alexander First Nation, AB & school garden \\
\hline First Nations Wildcrafters & Tseshaht First Nation, BC & $\begin{array}{l}\text { culturally sustainable forest } \\
\text { management training }\end{array}$ \\
\hline $\begin{array}{l}\text { Four Arrows Regional Health Authority } \\
\text { Food Security Programs }\end{array}$ & $\begin{array}{l}\text { Island Lake Communities; Wasagamack, } \\
\text { Ste. Theresa Point, Garden Hill \& Red } \\
\text { Sucker Lake First Nations, MB }\end{array}$ & community garden and poultry \\
\hline Indigenous Food First Website & Canada-wide & traditional foods education \\
\hline Ladybug Garden \& Greenhouse Project & T'Sou-ke First Nation, BC & traditional foods education \\
\hline $\begin{array}{l}\text { Masset-Haida Gwaii Farm to School Salad } \\
\text { Bar Program }\end{array}$ & Haida Gwaii, BC & $\begin{array}{l}\text { traditional foods education and } \\
\text { healthy eating program }\end{array}$ \\
\hline Matheson Island Community Garden & Matheson Island, MB & community garden \\
\hline Muskoday Organic Grower's Co-op & Muskoday First Nation, SK & market garden cooperative \\
\hline Nelson House Country Foods Program & $\begin{array}{l}\text { Nisichawayasihk Cree Nation (Nelson } \\
\text { House), MB }\end{array}$ & country foods program \\
\hline Splatsin Cultural Use Market Garden & Splatsin Band, Shuswap Nation, BC & traditional foods market garden \\
\hline $\begin{array}{l}\text { Traditional Foods \& Healthy Eating } \\
\text { Program }\end{array}$ & La Ronge, SK & traditional foods education \\
\hline Turtle Mountain Metis Community Garden & Turtle Mountain Local Metis, MB & community garden \\
\hline Water Guardians Program & $\begin{array}{l}\text { Pine Creek First Nation, Sagkeeng First } \\
\text { Nation, Fisher River Cree Nation, \& Duck } \\
\text { Bay, MB }\end{array}$ & biomonitoring education program \\
\hline $\begin{array}{l}\text { Vancouver Island Traditional Foods } \\
\text { Conference }\end{array}$ & $\begin{array}{l}\text { Various- Vancouver Island \& Coastal } \\
\text { Communities, BC }\end{array}$ & traditional foods education \\
\hline
\end{tabular}


For the final phase of the research, participants were invited to an Indigenous food gathering on the land in Peguis First Nation. No recordings or notes were taken at the event, and my observations and experiences of it have been written elsewhere. This component of the research was ceremonial, deeply personal, and was written as a narrative in which I examined self in reflection to the event (Martens, 2017).

Transcribed interviews were analyzed by hand using a tactile approach of keywords on a series of papers covering my floor. These keywords were based on the symbol (Absolon, 2011; Kovach, 2009) of hands that had appeared throughout the research and later used with a circle model with the guidance of my committee and Elders. On the advice of one of my committee members, I explored the use of metaphor in Indigenous research and realized that many of the interviews talked about hands being involved in food work (Absolon, 2010; Hart, 2002; Lavallée, 2007). In creating key themes, I wrote about ways that hands appeared and were discussed in the interviews (Martens, Cidro, Hart \& McLachlan, 2016). One Elder, in particular, sat with me as I laid out the various pieces of paper containing key themes from the research. It is important to note that he did not influence the process but rather listened and asked questions about why I had placed things where I did. The results are presented as the four elements of Indigenous food sovereignty (Figure 1). Importantly, this circle model and the four elements were presented back to the participants, revisions were made to the model based on their feedback, and I was given permission to move forward on their behalf. Figure 1 presents the model that I created using the interviews and feedback from participants.

\section{Results}

Throughout my interviews, the image of hands appeared repeatedly and created a fitting metaphor or symbol for the research. The following poem emerged from a journal I kept during the process.
I think of how those hands plant a seed or tend to the earth. I think of those hands as filleting the fish or skinning the muskrat, tanning the hides. I think of those hands as healing with the power of touch, knowledge, and prayer, through the work of our healers. Or the hands that pick the medicine that make us well. They are the hands that sound the drum to awaken our spirit. The hands that reach out to help and share our food with family and friends, the hands that stir the pot of stew. They are the hands that write letters to government or hold protest signs when our land is in danger. They are the hands that can extend out to our neighbors, across provinces and territories to share and trade and create a powerful network of food. And they are the hands that are brown, or red, or white, or some combination of those colors, that speak to our ancestors; they remind us who we are and where we come from. They are the hands that have been oppressed-tied by colonialism—or slapped by government, by residential schools, by racism. And of course, there are the hands of oth-

Figure 1. Elements of Indigenous Food Sovereignty

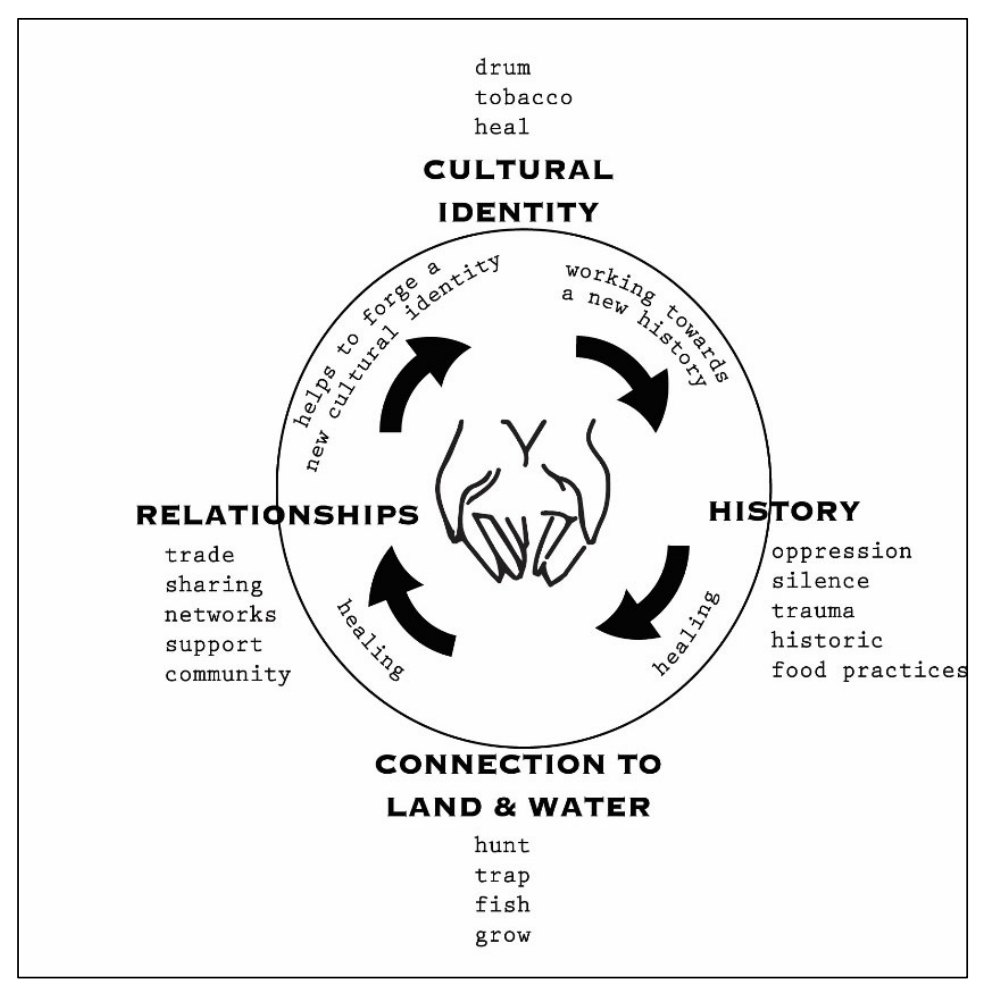


ers that have covered our mouths, trying to silence Indigenous voices. (Martens, 2015, p. 37)

Figure 1 presents the four elements of Indigenous food sovereignty-history, connection to the land, relationships, and cultural identity-revealed through the participants and my own involvement in the projects. Each of the four elements will be discussed below.

\section{History}

Indigenous food sovereignty is a living, breathing way of life found in the past and present and envisioned for future generations. For Indigenous peoples, hope remains despite the history of starvation, control, and colonization of food systems (Burnett, 2010; Carter, 1990; Daschuk, 2013; Lux, 2001; Mosby, 2013; Shewell, 2004). In discussing their food programs and projects, participants described the need to return to the past when food came from the land and teachings came from Elders. In talking about the Muskoday Organic Grower's Coop in Saskatchewan, Harvey Knight explained, "We're also going to our Elders to re-learn our history of agriculture that goes back for thousands and thousands of years. We're reclaiming our right to grow these Indigenous foods.... We live with them, we co-existed with them on an equal basis, we have agreements made once a long time ago."

In British Columbia, The Traditional Foods Conference, once held annually on Vancouver Island, has helped provide more links to the past for people all over the island, providing support for re-invigorating traditional food practices:

And so the traditional foods conference, on a personal level, really enabled me to be able to be more well equipped and more knowledgeable about traditional food systems in my particular area and to not only take that knowledge to and know more about foods, but actually take it another step further and breathe life back into those practices. (John Rampanen)

Acknowledging the losses of land and culture through colonialism has been critical in order for these communities to move forward. Research par- ticipants described multiple pathways towards reclamation. As Douglas Hart explains, the Nelson House Country Foods Program in Manitoba has experienced an increase in community engagement: "People utilize it. Every day, they come and get stuff for themselves. Whatever we have. Moose meat, caribou. We berry pick, too. And we have our community garden.” By providing opportunities for people to go back to the land and back to land-based diets, history lives on.

\section{Connection to the Land}

Land is fundamental to Indigenous ways of knowing and being. King (2012) shares, "land has always been a defining element of Aboriginal culture. Land contains the languages, the stories, and the histories of a people. It provides water, air, shelter, and food. Land participates in the ceremonies and the songs. And land is home" (p. 218). Indeed, it is the foundation for all learning and development. Often, Indigenous food sovereignty is considered to be specific actions taking place on the land: the harvest, the hunt, the gather, and the seed and sow. And yet, spending time on the land and with the land takes many shapes for Indigenous peoples. (Re)Learning and practicing traditional languages, for example, are land-based practices. Indigenous languages are a form of communication with creation that can help to bring people and place together.

In talking about First Nations Wildcrafters, an Indigenous organization that works with and trains others on sustainable forest management, Keith Hunter explains the fluidity of language and the land:

When I see-my most personal satisfaction is when we see the older ones, not only during mushroom season, but berry season too, when you see the older generation taking the kids out with them, they're telling their stories and the history of the land in their language. That language vitality, the continuity of language, story, and place.

Returning to the land to nourish the body and soul is an often overlooked component of Indigenous food sovereignty, yet it is critical to well- 
being. The land can be a source of healing, as Alma Bear describes of her experience with the Flying Dust Cree-8 Workers Co-op in Saskatchewan: "I would just like to move to the garden, because the micro-organisms always get me going. And when I get stressed out, off to the garden I go. I find it so peaceful."

Relationships to the land are also important in helping to fulfill the roles and responsibilities we have made towards the land as caretakers. Mike Christian (Splatsin First Nation, British Columbia) shares how this idea helps guide an agro-forest initiative in his territory:

So that's another project that we're going through this agroforestry thing, is we're kind of indigenizing what they call agroforestry because it's almost like in reverse. You know, that's how our ancestors used to take care of the land so if you really think when did this start? It started long ago when our ancestors managed the land, right?

Food sovereignty began with ancestors, and not just humans. The water, the soil, the plants, the animals, and everything in between provides lessons, opportunities, and the gift of life.

\section{Relationships}

Indigenous food sovereignty embodies a caring quality that extends to the land, water, and each other. IFS embraces an awareness of the intimate connection between people and all of creation. Relationships are the next act of the processes of food sovereignty as described by the participants. These relationships include the physical connection to the land, where hands meet earth and water; and the connections between people, where hands meet hands, and hands meet hearts. Here we can see the practices of gratitude, nurturing, and also accountability. William Gladue, of the Flying Dust Cree-8 Worker's Co-op in Flying Dust, Saskatchewan, notes the importance of working together and sharing to uphold relationships:

We already have a couple nations that have started their gardens already. And that's by coming and giving a tour of the garden. Basi- cally, just that alone is recognition for us because we're trying to take this project as far as it can go, actually. As far as we're concerned, it's already there, now. And we'd like to keep that momentum going.

Networks of like-minded people that can support and encourage these initiatives are key to increasing awareness of Indigenous food systems. Care within nations is also important. Many Indigenous cultures teach the importance of community efforts to ensure that no one in the community goes hungry. Indeed, for the Nelson House Country Foods Program in Nelson House, Manitoba, that is why the program started. Douglas Hart, manager of the program that gathers and distributes country (or traditional, original, cultural) foods in the community, explains,

We were supposed to look after the elderly. People who can't hunt, 55 plus. That's how it started. It's not only the Elders. We do it for the whole community, infirm, people are not making enough money, they usually come and get their stuff here. Usually distribute like, it's free, you don't charge them, you just give it away free.

Nurturing relationships also help to build support for community-based food projects. Many of the food projects highlighted depend on the support of volunteer community members. The importance of support for and from the community is critical to these undertakings. Crystal Stewart, treasurer for the Turtle Mountain Métis Garden in Manitoba, shares how support can enhance the process of re-building a food system:

So, it was amazing how many people said 'oh, no' when we tried to pay them for the use of their equipment, and they'd say 'no, that's quite all right' I'm glad to see the community's doing this.... That was Mom's biggest smile about the whole project, was sitting back and seeing all of these in-kind gestures coming in and how unbelievable it was to realize there was such generosity. This day and age you think that doesn't happen as much anymore as in the old 
days when everybody helped each other. But apparently, the generosity's still there.

Many of these food projects brought forward values central to Indigenous communities, such as kindness, sharing, caring, and respect. Participants discussed these values as being key to their culture and the food projects. Importantly, they are the foundation of relationships.

\section{Cultural Identity}

Cultural identity is the fourth and final element of Indigenous food sovereignty as described by the research participants. This is the place where how one views the world and lives one's culture helps to develop identity. It sits in your body, your mind, your heart, and in your spirit.

Cultural identity is a deeply complex topic (see, for example, Corntassel, 2003; Weaver, 2001). However, participants shared that by practicing food sovereignty, they experienced a strong sense of belonging and identity. Because many food practices are grounded in cultural and ceremonial practices central to Indigenous ways of life, participants viewed their projects as contributing to a stronger sense of being Indigenous and of building nationhood and community.

Cultural knowledge around food is seen as vital for youth. As a means to transfer knowledge, landbased food practices can support the development of strong, healthy Indigenous communities connected to the land. Gerralynne Cochrane shares her wish for the Back to the Land Camp in Peguis, MB:

I would like to have this camp year-round. I would like more kids to come out. I would like to go into schools and be able to sit down and talk to parents, teachers, principals. I'd like to get them all together and explain it all to them. Like, children, they're our future. But don't jeopardize their future, too.

Participants also described the role of Elders, language, and women as integral to revitalizing Indigenous culture and identities. Christine George of the T'Sou-ke Nation explains how the Ladybug Garden and Greenhouse Program in British
Columbia has expanded to incorporate language and ceremony: "We also take our members and youth out onto our traditional territories for hikes to practice our culture by way of prayers and blessings, exercise, plant identification, and language practices.... That's like a classroom out on the beach." Youth and Elder relations are critical to Indigenous food sovereignty processes. Elders are knowledge holders in Indigenous culture, while youth are the gifts of the future.

These food projects help build stronger identities by providing the means to revitalize historical and contemporary food practices grounded in Indigenous epistemologies. Indeed, John Rampanen explains how these relationships were centered with the Vancouver Island and Coast Communities Traditional Foods Conferences in British Columbia, and what it has meant to him on a personal level:

And being a part of that process has been a magical experience for me, that has really transformed who I am as a person, as a father, as my family to the point, that I've moved myself from the city to my traditional territory in a very rural, remote section of Vancouver Island, to be directly on the land, to be able to harvest those Indigenous foods to be able to live in that lifestyle as opposed to only talking about it.

\section{Discussion}

\section{Political Implications}

Indigenous food sovereignty, as a concept and way of life, is challenging to describe and even more difficult to define. A significant factor remaining unexamined in this study is how and where political sovereignty relates to Indigenous food sovereignty. This is also true for much of the literature on Indigenous food sovereignty. For this study, all research questions were centered on the community food projects themselves. The research participants made no mention explicitly of political sovereignty. That is not to suggest that elements of political sovereignty were not present in these projects, however. Projects such as advocacy work, returning to a matriarchal system of governance, 
and the self-determined research in this area are ways that communities demonstrated the link between food and politics in an attempt to move toward more self-determination.

Conversations around the political implications of food sovereignty for Indigenous peoples and communities would be valuable for the future. Participants did reveal how politics interfered or challenged their food sovereignty initiatives, and so this is an area that needs to be examined from multiple angles. Issues around lack of funding, resources, and support were often viewed as being political but vital to the success of these initiatives. At the same time, I am mindful of Alfred and Corntassel's (2005) argument that political sovereignty is neither adequate nor appropriate for Indigenous peoples, as it is too steeped in the processes of colonization. Decolonizing Indigenous food systems is a multifaceted and deeply individual process. Communities should have the opportunity to confront colonization on their own terms.

\section{Indigenous Food Sovereignty and Research as Self-determination}

In seeking research participants, I did not attempt to define the term Indigenous food sovereignty, nor did I create criteria for the initiatives representing Indigenous food sovereignty. I let the communities, individuals, and organizations I spoke with determine whether they felt their project exemplified Indigenous food sovereignty. From there, we moved toward the research process. In talking with participants about what Indigenous food sovereignty looks like, many participants described feelings. They explained how the project felt to them or the people involved in their projects. This speaks to the holistic nature of Indigenous food sovereignty (Absolon, 2011; Morrison, 2011; PFPP, 2011). All the community food projects presented in this study sought to create change and the opportunity to support healthier communities. Health was not seen as merely a physical state, but as a balance between the physical, emotional, mental, and spiritual components of life, or "being" in a state often referred to as well-being (Adelson, 2000; Struthers, 2000).

Indigenous food sovereignty is participatory and action-oriented (Morrison, 2011). In the food projects studied, the heart and hands of the work came together to carry out the tasks and responsibilities set out by Indigenous ancestors. Ceremony, prayer, song, and celebration were used by project participants for a broader, more intentional vision of food sovereignty that included the use of food as healer. Ceremony, prayer, song, and celebration were also used by the project participants to help connect to a greater vision of their project and to work toward food as healing in their communities (Morrisseau, 1998; Stevenson, 1999). In listening to the participants, I was reminded of the words of Cree scholar Michael Hart (2010), who asks that in Indigenous research, we listen with our whole being. This perspective was critical to the processes of this research project and the richness of data that emerged. Nonetheless, Indigenous food sovereignty is challenging to define and means different things to different people_-across nations, geographies, and through a variety of circumstances stemming from treaty agreements, residential school experiences, and the impacts of large-scale extraction, for example (Alfred \& Corntassel, 2005; Coté, 2016; Daigle, 2017). In order to make space for these complexities, I left the decision about whether a project was a "true" example of Indigenous food sovereignty with those who know their work and communities the best: the project participants.

Self-determination is imperative to Indigenous research. Smith (1999) states: "It becomes a goal of social justice ... and necessarily involves the process of transformation, of decolonization, of healing, and of mobilization as peoples" (p. 116). Thus, I made space for communities to describe food sovereignty in their own ways. This further aligns with Morrison's (2011) point that there is no singular definition of Indigenous food sovereignty: "While there is no universal definition of food sovereignty that reflects all of the realities of the myriad of Indigenous communities around the world, the underlying principles of Indigenous food sovereignty are based on our responsibilities to uphold our distinct cultures and relationships to the land and food systems" (p. 97).

\section{Indigenous Food Sovereignty as Process}

In reviewing the model and the results of this 
research, participants were given the opportunity to share their feedback through a set of further questions; however, responding was optional. All participants agreed with and were in support of the model presented (Figure 1). For the 12 participants who responded to the optional questions, one idea became clear: Indigenous food sovereignty is a journey, and it is both ongoing and evolving. These projects were seen as opportunities to build interest within the community, to feed people, to bring back traditional food values and practices, to advocate for the land and for the people of the land, and to re-affirm Indigenous identities. Participants shared words such as "process," "journey," and "pathway" to describe their response to the model, and indeed in reflection of their project as part of the overall study. This was a critical lesson for me. Christine George (Ladybug Garden \& Greenhouse Program, BC) positively responded to the model by stating, "there are so many versions by so many nations; every one is different and deals with their Indigenous foods slightly different from each other." Process is key within Indigenous cultures (Cajete, 1994; Simpson, 2002), and it is necessary to have the tools, resources, and supports to move toward Indigenous food sovereignty. The model presented here, in the form of a circle, represents the idea of process within Indigenous food sovereignty; McCabe (2008) explains that the medicine wheel represents process. Indigenous food sovereignty, in this study, was not viewed as the end result; rather, it was part of a cycle of doing the work to feed people and continue to articulate the struggle for Indigenous self-determination.

\section{Conclusion}

The four elements that emerged through this research project- history, connection to the land, relationships, and cultural identity - help provide a larger foundation for examining Indigenous food sovereignty. The model developed through this research is based on the stories shared by community members and how they saw their voices and work portrayed. Unpacking the language, tensions, and opportunities of Indigenous food sovereignty is not easy and requires many more discussions.
The knowledge translation around this research was critical. The food projects presented here are examples of how to create local food system elements that reflect the diverse realities of Indigenous cultures and food systems. With each and every interview, I tried to consider why what the participants were sharing with me was important. Having the opportunity to undertake conversations around the complexities and connections between land, food, culture, justice, education, healing, and well-being to further my own growth as an Indigenous person is a privilege not lost on me. At the same time, my identity as an Indigenous person on her own journey toward food sovereignty helped me relate to the information shared with me in a more intuitive way.

I realized that missing in the quest to describe the mechanics of Indigenous food systems was how food sovereignty fit into a larger social, cultural, and political narrative (Alfred, 2009; Coté, 2016; Morrison, 2011). It is missing because of the systemic damages that have occurred and continue to occur through large-scale resource extraction, racism (including environmental racism), and the loss of Indigenous women and girls, to name but a few major challenges. These are issues Indigenous peoples are facing daily. Indigenous food programs, policies, practices, and initiatives must not be considered in isolation, with fisheries siloed from forestry, from tribal government and health, and so on and so on. Food, for Indigenous cultures, doesn't exist in isolation from other parts of life and being. There is an incredible opportunity to create stronger and healthier relationships with food and the land through our connections. Indigenous food sovereignty is a historical and lived experience that, in many cases, has been dismantled by colonialism. It has been examined as a response to food insecurity, and yet it is so much more powerful. We are at a moment in time, following along the footsteps of the Idle No More movement, where politicizing the term "Indigenous food sovereignty" to resist the structures created by colonialism may just be what is needed for a resurgence in culture (Mullinix, 2015). But make no mistake; this is not only a "cultural resurgence," but also a political one (Simpson, 2017). 


\section{References}

Absolon, K. (2010). Indigenous wholistic theory: A knowledge set for practice. First Peoples Child \& Family Review, 5(2), 74-87. http://journals.sfu.ca/fpcfr/index.php/FPCFR/article/view/95/160

Absolon, K. E. (2011). Kaandossiwin: How we come to know. Black Point, Nova Scotia: Fernwood Publishing.

Adelson, N. (2000). Being alive well': Health and the politics of Cree well-being. Toronto: University of Toronto Press.

Alfred, T. (2009). W asáse: Indigenous pathways of action and freedom. Toronto: University of Toronto Press.

Alfred, T., \& Corntassel, J. (2005). Being Indigenous: Resurgences against contemporary colonialism. Government and Opposition, 40(4), 597-614. https://doi.org/10.1111/j.1477-7053.2005.00166.x

Anderson, M. C., \& Robertson, C. L. (2011). Seeing red: A bistory of Natives in Canadian newspapers. Winnipeg, MB: University of Manitoba Press.

Andrée, P., Cobb, M., Moussa, L., \& Norgang, E. (2011). Building unlikely alliances around food sovereignty in Canada. Studies in Political Economy, 88(1), 133-159. https://doi.org/10.1080/19187033.2011.11675012

Battiste, M., Bell, L., \& Findlay, L. M. (2002). An interview with Linda Tuhiwai Te Rina Smith. Canadian Journal of Native Education, 26(2), 169-201.

Bell-Sheeter, A. (2004). Food sovereignty assessment tool. Fredericksburg, VA: First Nations Development Institute. Retrieved from https://www.indigenousfoodsystems.org/sites/default/files/tools/FNDIFSATFinal.pdf

Burnett, K. (2010). Taking medicine: Women's healing and colonial contact in southern Alberta. Vancouver: University of British Columbia Press.

Cajete, G. (1994). Look to the mountain: An ecology of Indigenous education. Durango, Colorado: Kivaki Press.

Cajete, G. (Ed.). (1999). A people's ecology: Explorations in sustainable living. Santa Fe, New Mexico: Clear Light Publishers.

Carter, S. A. (1990). Lost harvests: Prairie Indian reserve farmers and government policy. Montreal: McGill Queen's University Press.

Cidro, J. \& Martens, T. (2014). Eating Indigenous in the city: The limited scope of food sovereignty for Indigenous people in urban contexts. International Journal on Biodiversity Watch, 4, 53-64.

Corntassel, J. (2003). Who is Indigenous? 'Peoplehood' and ethnonationalist approaches to rearticulating indigenous identity. Nationalism and Ethnic Politics, 9(1), 75-100. https://doi.org/10.1080/13537110412331301365

Coté, C. (2016). "Indigenizing” food sovereignty. Revitalizing Indigenous food practices and ecological knowledges in Canada and the United States. Humanities, 5(3), 57. https://doi.org/10.3390/h5030057

Daigle, M. (2017). Tracing the terrain of Indigenous food sovereignties. The Journal of Peasant Studies, 46(2), $297-315$. https://doi.org/10.1080/03066150.2017.1324423

Daschuk, J. (2013). Clearing the plains: Disease, politics of starvation, and the loss of Aboriginal life. Regina, Saskatchewan: University of Regina Press.

Desmarais, A., \& Wittman, H. (2014). Farmers, foodies, and First Nations: Getting to food sovereignty in Canada. The Journal of Peasant Studies, 41(6), 1153-1173. https:/ / doi.org/10.1080/03066150.2013.876623

First Nations Health Council. (2009). Healthy food guidelines for First Nations communities. Retrieved September 1, 2018, from the First Nations Health Council website: http://www.fnha.ca/documents/healthy food guidelines for first nations communities.pdf

Follett, A. (2010). Breaking the neocolonial news cycle: Communicating sustainability from a First Nations' perspective. Canadian Journal of Applied Research, 1(1), 21-47. https://www.cdnjournalappliedresearch.ca/index.php/cjar/index

Grey, S. \& Patel, R. (2015). Food sovereignty as decolonization: Some contributions from Indigenous movements to food system and development politics. Agriculture and Human V alues, 32(3), 431-444. https://doi.org/10.1007/s10460-014-9548-9

Harding, R. (2006). Historical representations of aboriginal people in the Canadian news media. Discourse \& Society, 17(2), 205-235. https://doi.org/10.1177/0957926506058059

Hart, M. A. (2002). Seeking mino-pimatisiwin: An Aboriginal approach to helping. Blackpoint, Nova Scotia: Fernwood Publishing.

Hart, M. A. (2010). Indigenous worldviews, knowledge, and research: The development of an Indigenous research paradigm. Journal of Indigenous Voices in Social Work, 1(1), 1-16. http://hdl.handle.net/10125/15117 
Health Canada. (2007). Canadian community health survey cycle 2.2, nutrition 2004: Income-related household food security in Canada. Retrieved from https://www.canada.ca/content/dam/hc-sc/migration/hc-sc/fnan/alt formats/hpfb-dgpsa/pdf/surveill/income food sec-sec alim-eng.pdf

Kamal, A. G. \& Thompson, S. (2013, September). Recipe for decolonization and resurgence: Story of O-Pipon-Na-Piwin Cree Nation's Indigenous food sovereignty movement. Paper presented at the Food Sovereignty: Critical Dialogue International Conference, Yale University, New Haven, Connecticut. Retrieved from https://iportal.usask.ca/action.php?sid=691142877\&url=https://www.tni.org/files/download $/ 46 \mathrm{kamal}$ thompso n_2013_0.pdf

Kelm, M.-E. (1999). Colonizing bodies: Aboriginal health and healing in British Columbia, 1900-50. Vancouver: University of British Columbia Press.

King, T. (2012). An inconvenient Indian. Toronto: Doubleday Canada.

Kovach, M. (2009). Indigenous methodologies: Characteristics, conversations, and contexts. Toronto: University of Toronto Press.

LaDuke, W. (2005). Recovering the sacred. Cambridge, Massachusetts: South End Press.

Lavallée, L. F. (2007). Physical activity and healing through the medicine wheel. Pimatisinin: Journal of Aboriginal and Indigenous Community Health, 5(1), 127-153. Retrieved from http://www.pimatisiwin.com/online/

Lux, M. K. (2001). Medicine that walks: Disease, medicine, and Canadian plains native people, 1880-1940. Toronto: University of Toronto Press.

Martens, T. (2015). Good news in food: Understanding the value and promise of Indigenous food sovereignty in western Canada (Master's thesis). University of Manitoba, Winnipeg, Manitoba. http://hdl.handle.net/1993/30825

Martens, T. (2017). Looking inwards, looking outwards: Reflecting on an Indigenous research approach. In C. Anderson, C. Buchanan, M. Chang, J. Sanchez Rodriguez, \& T. Wakeford (Eds.), Everyday experts: How people's knowledge can transform the food system (pp. 1-13). Coventry, UK: Coventry University. Retrieved from https://www.coventry.ac.uk/research/areas-of-research/agroecology-water-resilience/our-publications/everydayexperts-how-peoples-knowledge-can-transform-the-food-system/

Martens, T., Cidro, J., Hart, M., \& McLachlan, S. (2016). Understanding Indigenous food sovereignty through an Indigenous research paradigm. Journal of Indigenous Social Development, 5(1), 18-37. https://journalhosting.ucalgary.ca/index.php/jisd/article/view/58469

Masioli, I. \& Nicholson, P. (2010). Seeing like a peasant: Voices from La Via Campesina. In H. Wittman, A. Desmarais, \& N. Wiebe (Eds.), Food sovereignty: Reconnecting food, nature, and community (pp. 33-44). Halifax, Nova Scotia: Fernwood Publishing.

McCabe, G. (2008). Mind, body, emotions, and spirit: Reaching to the ancestors for healing. Counseling Psychology Quarterly, 21(2), 143-152. https://doi.org/10.1080/09515070802066847

McCallum, M. J. L. (2017). Starvation, experimentation, segregation, and trauma: Words for reading Indigenous health history. The Canadian Historical Review, 98(1), 96-113. https://doi.org/10.3138/chr.98.1.McCallum

McLachlan, S. M. (2014). "Water is a living thing”: Environmental and human health implications of the Athabasca Oil Sands for the Mikisew Cree First Nation and Athabasca Chipewyan First Nation in Northern Alberta. Retrieved from https://landuse.alberta.ca/Forms \%20and \%20Applications/RFR_ACFN\%20Reply \%20to \%20Crown $\% 20$ Submissio n\%206\%20-\%20TabD11\%20Report 2014-08 PUBLIC

Morrison, D. (2011). Indigenous food sovereignty: A model for social learning. In H. Wittman, A. Desmarais, \& N. Wiebe (Eds.), Food sovereignty in Canada: Creating just and sustainable food systems (pp. 97-113). Halifax, Nova Scotia: Fernwood Publishing

Morrisseau, C. (1998). Into the daylight: A wholistic approach to healing. Toronto: University of Toronto Press.

Mosby, I. (2013). Administering colonial science: Nutrition research and biomedical experimentation in Aboriginal communities and residential schools, 1942-1952. Social History, 46(91), 145-172. Retrieved from https://muse.jhu.edu/article/512043

Mullinix, K. (2015). Working with Indigenous peoples to foster sustainable food systems [Guest editorial]. Journal of Agriculture, Food Systems, and Community Development, 5(4), 3-6. http://dx.doi.org/10.5304/jafscd.2015.054.008 
Mundel, E., \& Chapman, G. (2010). A decolonizing approach to health promotion in Canada: The case of the urban Aboriginal Community Kitchen Garden Project. Health Promotion International, 25(2), 166-173. https://doi.org/10.1093/heapro/daq016

Patel, R. (2012). Food sovereignty: Power, gender, and the right to food. PLoS Medicine, 9(6), 1-4. https://doi.org/10.1371/journal.pmed.1001223

People's Food Policy Project [PFPP]. (2011). Resetting the table: A people's food policy project. Retrieved from the Food Secure Canada website: https://foodsecurecanada.org/sites/foodsecurecanada.org/files/FSC-resetting2012-8half11-lowres-EN.pdf

Porter, R. O. (2005). The decolonization of Indigenous governance. In W. A. Wilson \& M. Yellow Bird (Eds.), For Indigenous eyes only: A decolonization handbook (pp. 87-108). Santa Fe, New Mexico: School of American Research Press.

Rudolph, K. R. (2012). Close to the land: Connecting northern Indigenous communities and southern farming communities through food sovereignty (Master's thesis). University of Manitoba, Winnipeg, Manitoba. https://mspace.lib.umanitoba.ca/handle/1993/5231

Rudolph, K. R., \& McLachlan, S. M. (2013). Seeking Indigenous food sovereignty: Origins of and responses to the food crisis in northern Manitoba, Canada. Local Environment, 18(9), 1079-1098.

https://doi.org/10.1080/13549839.2012.754741

Shewell, H. E. Q. (2004). 'Enough to keep them alive': Indian social welfare in Canada, 1873- 1965. Retrieved from https://www.jstor.org/stable/10.3138/j.ctt1287s0k

Simpson, L. (2002). Indigenous environmental education for cultural survival. Canadian Journal of Environmental Education, 7(1), 13-25. https://cjee.lakeheadu.ca/article/view/271

Simpson, L. (2008). Oshkimaadiziig, the new people. In L. Simpson (Ed.), Lighting the eighth fire: The liberation, resurgence, and protection of Indigenous nations (pp. 13-21). Winnipeg, Manitoba: Arbeiter Ring Publishing.

Simpson, L. (2017). As we have always done: Indigenous freedom through radical resistance. Minneapolis: University of Minnesota Press.

Skinner, K., Hanning, R. M., Metatawabin, J., \& Tsuji, L. J. (2014). Implementation of a community greenhouse in a remote, sub-Arctic First Nations community in Ontario, Canada: A descriptive case study. Rural and Remote Health, 14(2), 1-18. Retrieved from http://www.ncbi.nlm.nih.gov/pubmed/24959925

Sloan-Morgan, V., \& Castleden, H. (2014). Framing Indigenous-settler relations within British Columbia's modern treaty context: A discourse analysis of the Maa-nulth treaty in mainstream media. The International Indigenous Policy Journal, 5(3), 1-19. https://doi.org/10.18584/iipj.2014.5.3.5

Smith, L. T. (1999). Decolonizing methodologies. New York: Zed Books.

Stevenson, J. (1999). The circle of healing. Native Social Work Journal, 2, 8-21. https://zone.biblio.laurentian.ca/handle/10219/456

Stroink, M. L., \& Nelson, C. H. (2009). Aboriginal health learning in the forest and cultivated gardens: Building a nutritious and sustainable food system. Journal of Agromedicine, 14(2), 263-269. https://doi.org/10.1080/10599240902739737

Struthers, R. (2000). The lived experience of Ojibwa and Cree women healers. Journal of Holistic Nursing, 18(3), 261-279. https://doi.org/10.1177/089801010001800307

Truth and Reconciliation Commission of Canada. (2015). Canada's residential schools: The legacy. Montreal: McGill-Queen's University Press.

Tuck, E. (2009). Suspending damage: A letter to communities. Harvard Educational Review, 79(3), 409-428. https://doi.org/10.17763/haer.79.3.n0016675661t3n15

Varese, S. (2010). Indigenous peoples contesting state nationalism and corporate globalism. In L. Meyer \& B. M. Alvarado (Eds.), New world of Indigenous resistance: Noam Chomsky and voices from North, South, and Central America (pp. 259-275). San Francisco: City Lights Books.

Vazquez, J. M. (2011). The role of indigenous knowledge and innovation in creating food sovereignty in the Oneida Nation of Wisconsin (Master's thesis). Iowa State University, Ames, Iowa.

https://doi.org/10.31274/etd-180810-1352 
Weaver, H. N. (2001). Indigenous identity: What is it and who really has it? The American Indian Quarterly, 25(2), $240-255$. https://doi.org/10.1353/aiq.2001.0030

Wilson, S. (2008). Research is ceremony: Indigenous research methods. Black Point, Nova Scotia: Fernwood Publishing.

Wittman, H., Desmarais, A., \& Wiebe, N. (2010). The origins and potential of food sovereignty. In H. Wittman, A.

Desmarais \& N. Wiebe (Eds.), Food sovereignty: Reconnecting food, nature, and community (pp. 1-12). Halifax, Nova Scotia: Fernwood Publishing.

Working Group on Indigenous Food Sovereignty [WGIFS]. (2011). Indigenous food sovereignty. Retrieved from http://www.indigenousfoodsystems.org/food-sovereignty 